\title{
Research article \\ Anticancer activity of secondary metabolites from Bauhinia tomentosa Linn. leaf - An in silico approach
}

\author{
R. Balabhaskar ${ }^{1}$, K. Vijayalakshmi ${ }^{2}$ \\ ${ }^{1}$ Research Scholar, Dept. of Biochemistry, Bharathiar University, Coimbatore, 641046, Tamil Nadu, India \\ ${ }^{2}$ Associate Professor, Dept. of Biochemistry, Bharathi Women's College, Chennai, 600108, Tamil Nadu, India
}

\author{
(Received: May 2020 Revised: July $2021 \quad$ Accepted: July 2021)
}

Corresponding author: R. Balabhaskar. Email: rbalabhaskar@gmail.com

\begin{abstract}
Introduction and Aim: Plants and plant derived products are used for human healthcare since the dawn of human civilization. About $80 \%$ of modern drugs are from natural origin. Many dreadful diseases like cancer are treated using drugs of natural origin. In the present study, a medicinal plant $B$. tomentosa Linn. leaves were investigated for its anticancer activity using A549 (Human Adenocarcinomic Alveolar Basal Epithelial Cells) cell lines. The active components were identified using GC-MS (Gas Chromatography- Mass Spectrophotometry) analysis. The aim of the present study was to identify potential lead compounds against various protein targets that are involved in lung carcinogenesis using molecular docking approach.
\end{abstract}

Materials and Methods: 3D structures of compounds reported from GCMS analysis of $B$. tomentosa were built using Chemsketch software. All the compounds analyzed exhibited antioxidant, anticancer, antimicrobial, antiinflammatory, and chemo preventive properties. Docking studies were performed using Molegro virtual docker (MVD).

Results: The docking studies revealed that the ligands either activate or inhibit the selected target proteins appropriately. This shows that the phytochemicals of $B$. tomentosa leaf was found to have appreciable anticancer activity.

Conclusion: The presence of various bioactive phytoconstituents justifies the use of the leaf for various ailments by traditional practitioners.

Keywords: Lung cancer; anticancer; ligands; phytochemicals; docking; MVD.

\section{INTRODUCTION}

$\mathrm{L}$

ung cancer is the third most common cancer worldwide. Cancer is the cause of more than $20 \%$ of the mortality worldwide (1). Most of the anticancer drugs that are currently used in chemotherapy are cytotoxic to normal cells also and hence leads to adverse side effects. Even therapeutically effective doses of cytotoxic drugs may produce severe irreversible reactions in normal tissues and become toxic to the cancer subjects.

Plants and plant derived products are used for human health care since the dawn of human civilization. Ayurveda and other plant-based remedies are a part of cultural heritage of India. About $80 \%$ of modern drugs are from natural origin. Many dreadful diseases like cancer are treated using drugs of natural origin. In the present study, the medicinal plant $B$. tomentosa Linn. Leaves were investigated for its anti lung cancer activity. To identify the anticancer activity, MTT assay, DNA fragmentation assay was done in earlier studies (2). The ethanol extract was then subjected to various gene and protein expression studies to demonstrate its role on both nucleic and epigenomic regulations in previous studies. From the results of the above studies, it was observed that the active components of EBT have anticancer activity. To identify the bioactive compounds, GC-MS analysis was done. Hence for lead compounds identification, in silico approach was followed.

The aim of the present study is to identify the potential lead compounds against various protein targets that are involved in lung carcinogenesis using molecular docking approaches and subjecting the identified molecules for ADME (Absorption, Distribution, Metabolism and Excretion) analysis. This work will help to identify the compounds, which may be used for therapeutic purpose.

\section{MATERIALS AND METHODS}

\section{Methodology}

All the computational analysis was carried out using Molegro Virtual Docker (MVD) 5.0Å.

\section{Protein structure}

X-ray crystal structure and Solution NMR structure of the following proteins were retrieved from Protein Data Bank and the details of their resolution (Figure 1.1 to 1.6$)$, PDB ID was as follows: 

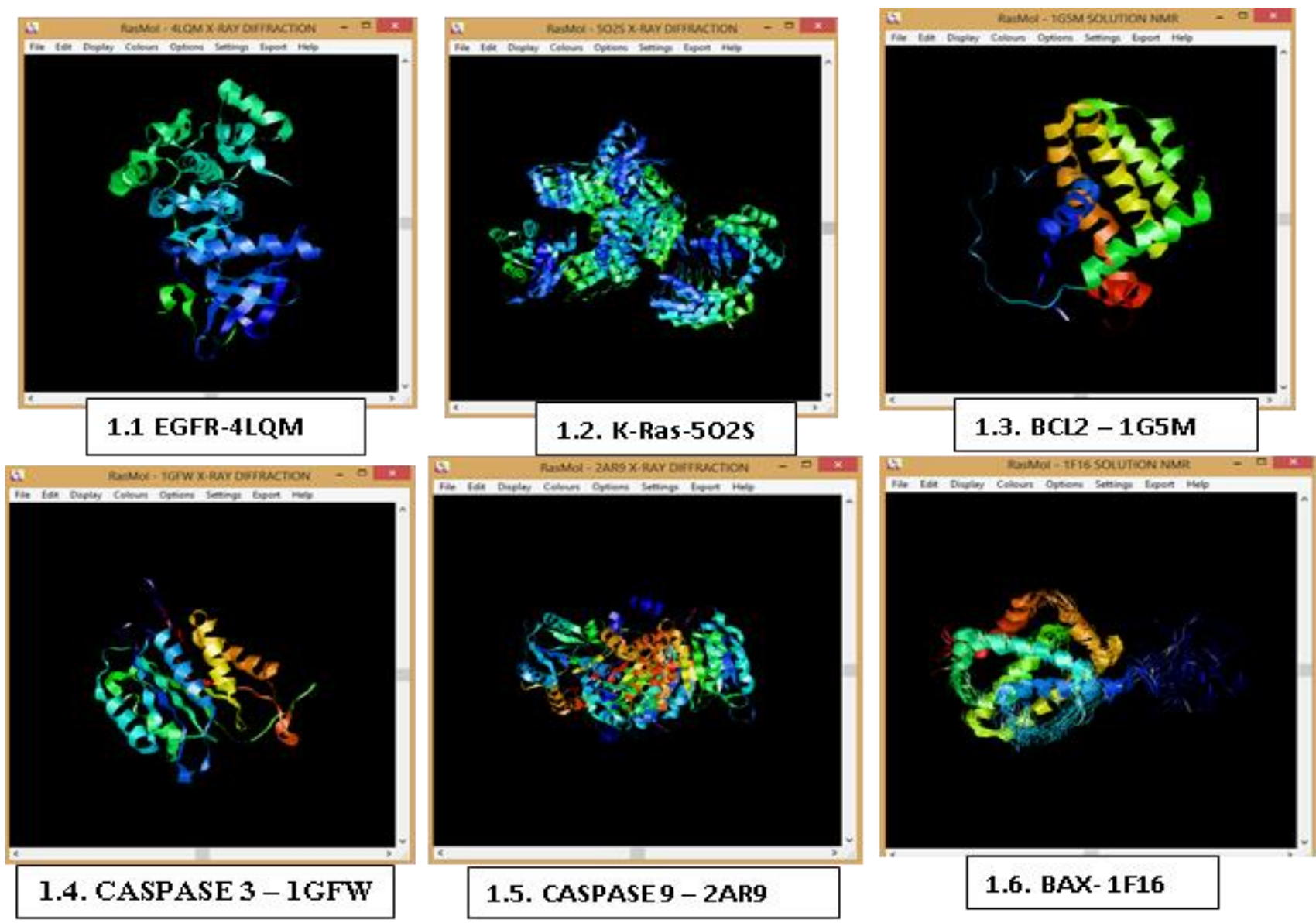

Fig. 1.1 to 1.6. Structure of Proteins

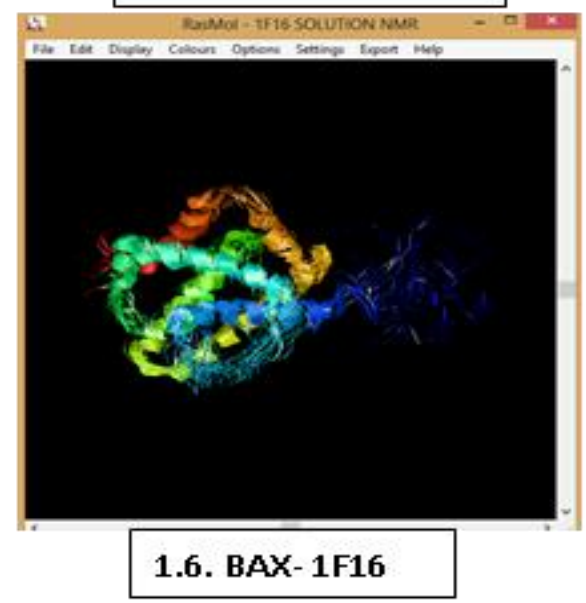

\section{Protein Preparation}

The target protein structures were prepared after careful removal of hetero atoms and water molecules and its electrostatic surface was generated.

\section{Ligand Preparation}

EBT (Ethanol extract of Bauhinia tomentosa) was subjected to GC-MS analysis to identify the bio constituents in earlier studies (3). The chemical

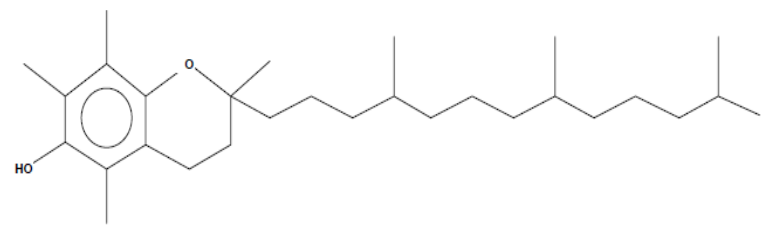

2.1. DL-.alpha.-tocopherol

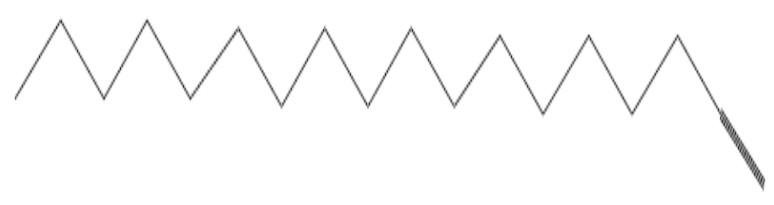

2.3. 1-octadecyne structures of all these molecules were drawn by using ChemSketch version 11.01 (http://www.acdlabs. com). Ligands were manually prepared using ligand preparation module of Molegro virtual docker. Bond order and hybridization assignment wherever missing and flexible torsion and the ligands were deducted. The structures of all docked ligands were shown in the Figure 2.1- 2.8.

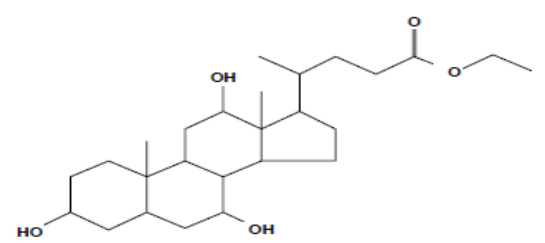

2.2. Ethyl iso-allocholate

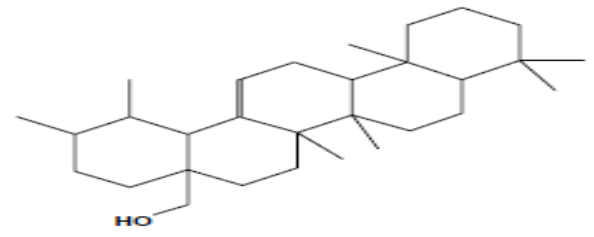

2.4. Urs-12-en-28-ol 


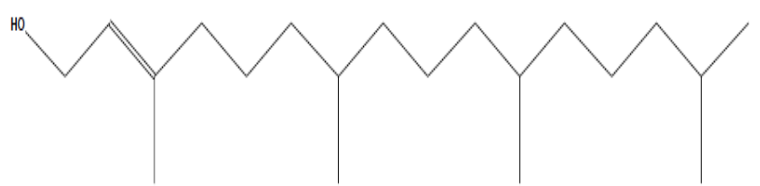

2.5. Phytol

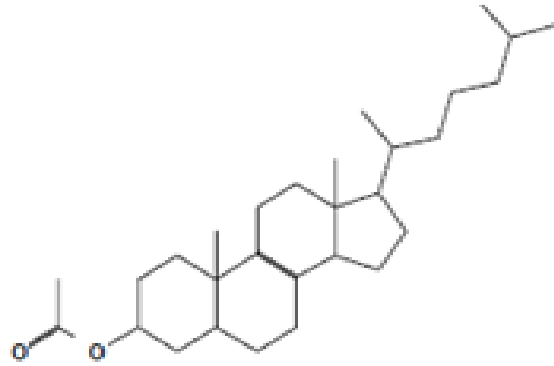

2.7. Cholest-8-en-3. beta.-ol,acetate

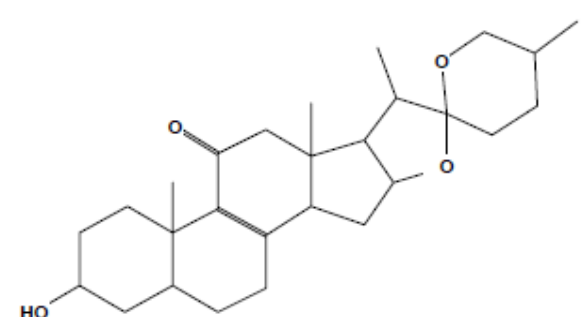

2.6. Spirost-8-en-11-one,3-hydroxy,(3.beta.,5.alpha.,14.beta.,20.beta.,22.bet a.,25r)-

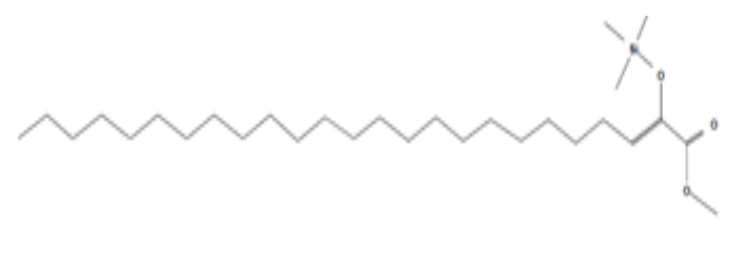

2.8. Pentacosenoic acid, 2-[(trimethylsilyl)oxy]-, methyl ester

\section{Docking}

MolDock scoring system is employed by MVD and it is based on a new hybrid search algorithm, called guided differential evolution. The guided differential evolution algorithm combines the differential evolution optimization technique with a cavity prediction algorithm. Differential evolution (DE) was introduced by Storn and Price in 1995 (4) and has previously been successfully applied to molecular docking. The use of predicted cavities during the search process, allows for a fast and accurate identification of potential binding modes (poses).

The intact protein structure was loaded on to MVD platform for docking process. Potential binding sites (also referred to as cavities or active sites) has been identified using the built-in cavity detection algorithm of MVD.

The search algorithm is taken as Moldock SE and numbers of runs are taken 10 and max iterations were 2000 with population size 50 with an energy threshold of 100. At each step least 'min' torsions/translations/rotations were tested and the one giving lowest energy was chosen. After the docking simulation was over, the poses which were generated were sorted by rerank score. The Rerank Score uses a weighted combination of the terms used by the MolDock score mixed with a few addition terms (the Rerank Score includes the Steric (by LJ12-6) terms which are Lennard-Jones approximations to the steric energy - the MolDock score uses a piecewise linear potential to approximate the steric energy (5). The docking was subjected towards the amino acid residues which were found to be part of interaction between HTSPs and VOPs. The grid resolution was set at $0.3 \AA$. The maximum interaction was set at 1500 and maximum population size 50 .

\section{RESULTS}

The GC-MS analysis of EBT identified 14 bioactive components. Out of 14 compounds, 8 compounds were found to have potential biological activity. Hence docking analysis of these 8 compounds was done in the present study. All the eight ligands were docked with these 6 proteins targets using MVD.

\section{Docking with EGFR}

The docking score (Moldock score) and rerank score of all the eight ligands with EGFR (Table 1). Among 8 ligands, Ethyl isoallocholate was found to have the least docking score of -111.809 and the least rerank score of -86.1456 and it formed 5 hydrogen bonds with Asp 855, Lys745, Asp 837 and Asn 842 (Figure 3.1- 3.3). This is followed by DL-Alpha tocopherol with -108.436 as moldock score and -89.9372 as rerank score. Though it has second least score, it does not form any hydrogen bonds with the protein target. Third best docked ligand is urs-12-en-28-ol. It has a moldock score of -101.685 and rerank score of 35.8199. It forms 2 hydrogen bonds with Cys797 and Arg841. Phytol was found to have a moldock score of -97.7472 and rerank score of -74.6896 . It forms 3 hydrogen bonds with Ala722, Phe 728 and Leu747. Like Alpha tocopherol, 1-octadecyne also does not form any hydrogen bond though it has moldock score of -90.4976 and rerank score of -68.5962 . Cholest-8en-3-beta-ol-acetate forms 1 hydrogen bond with Glu762 of EGFR with a moldock score-89.9248 and rerank score of -67.8335 . Pentacosenoic acid, 2[(trimethylsilyl)oxy]-methyl ester was found to dock with EGFR with moldock score -86.5873 and rerank 
score as -54.6394. It also forms 2 hydrogen bonds with Lys754 and Gly874. The least docked ligand is the spirost-8-en-11-one,3-hydroxy-(3-Beta-5-Alpha14-beta-20-beta-22-beta-25r). It has a moldock score of -37.6546 and rerank score of -40.1183 . It was found to 2 form hydrogen bonds with Lys754 and Gly874 of EGFR.

Table 1: List of amino acid residues involved in protein-protein interaction between EGFR and selected ligands as predicted by SHARP

\begin{tabular}{|c|c|c|c|c|c|}
\hline Name & $\begin{array}{l}\text { MolDoc } \\
\text { k-Score }\end{array}$ & $\begin{array}{c}\text { Rerank } \\
\text { Score }\end{array}$ & H Bond & $\begin{array}{c}\text { No. of } \mathrm{H} \\
\text { Bonds }\end{array}$ & $\begin{array}{c}\mathrm{H} \text { bond forming Amino } \\
\text { Acids }\end{array}$ \\
\hline DL-.Alpha.-tocopherol & -108.436 & -89.9372 & 0 & 0 & N. A. \\
\hline 1-octadecyne & -90.4976 & -68.5962 & 0 & 0 & N.A. \\
\hline Phytol & -97.7472 & -74.6896 & -5.49383 & 3 & Ala722, Phe723, Leu747 \\
\hline Ethyl iso-allocholate & -111.809 & -86.1456 & -11.1542 & 5 & $\begin{array}{c}\text { Asp855, Lys745, Asp837, } \\
\text { Asn842 }\end{array}$ \\
\hline Urs-12-en-28-ol & -101.685 & -35.8199 & -4.64758 & 2 & Cys797 and Arg841 \\
\hline $\begin{array}{c}\text { Pentacosenoic acid, 2- } \\
\text { [(trimethylsilyl)oxy]-, methyl ester }\end{array}$ & -86.5873 & -54.6394 & -4.73461 & 2 & Lys754, Gly874 \\
\hline $\begin{array}{l}\text { Spirost-8-en-11-one,3-hydroxy-, } \\
\text { (3.beta.,5.Alpha.,14.beta.,20.beta., } \\
\text { 22.beta.,25r)- }\end{array}$ & -37.6546 & -40.1183 & -5 & 2 & Lys754, Gly874 \\
\hline Cholest-8-en-3.beta.-ol, acetate & -89.9248 & -67.8335 & -0.81071 & 1 & Glu762 \\
\hline
\end{tabular}

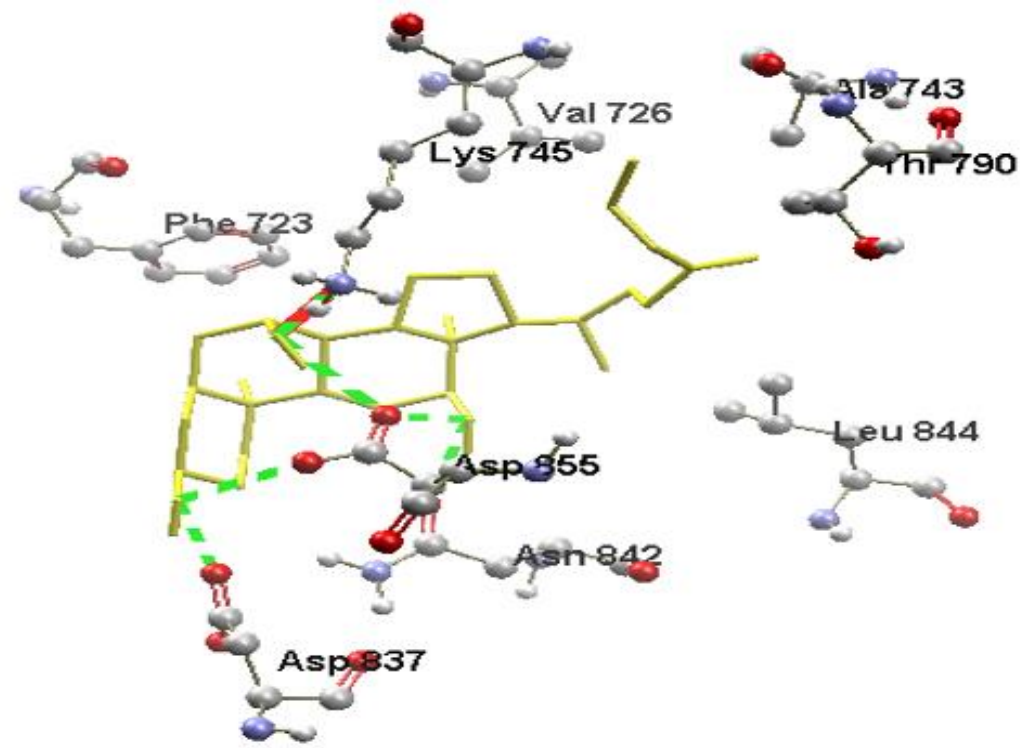

Fig. 3.1: Interaction Profile of Ethyl iso-allocholate with Human EGFR (PDB ID: 4LQM) Docking view of Ethyl isoallocholate (Shown in Yellow Stick model) within the active site of Human EGFR (11 Hydrogen Bonds with Asp855, Lys745,Asp837,Asn842)

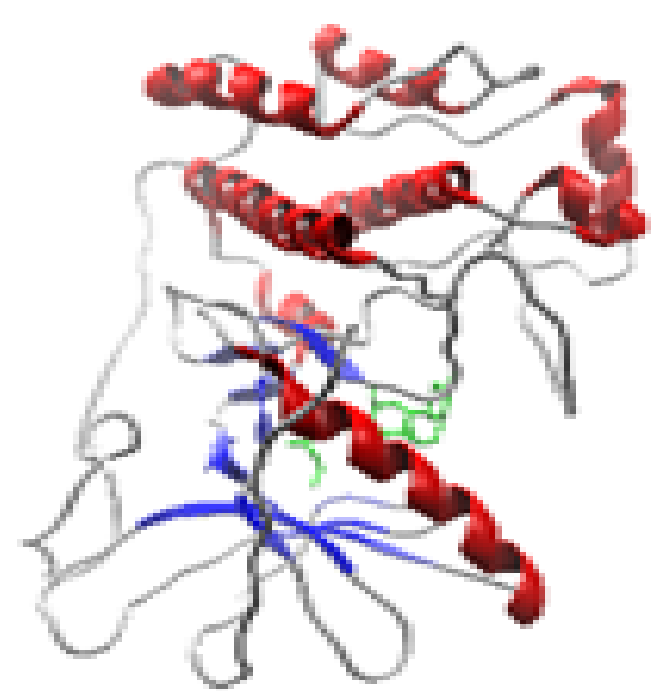

Fig. 3.2: Secondary Structure View of EGFR in complex with Docked Ethyl iso-allocholate (Shown in Green Stick Model) 


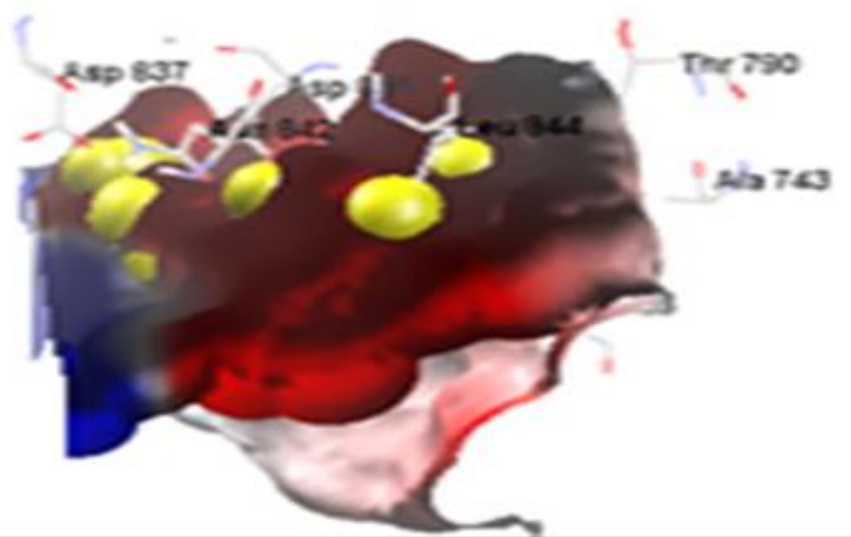

Fig. 3.3: Electrostatic Interactions between Ethyl iso-allocholate (Shown in Yellow Space fill) and Human EGFR

\section{Docking with K-Ras}

The docking score and the rerank score of the eight ligands with K-Ras was depicted in Table 2. When docked with K-Ras, all the 8 ligands showed a range of moldock score from -113.594 to -75.2325 . Ethyl isoallocholate was the lead compound with the lead moldock score and rerank score of about -113.594 and -93.3045 respectively. It forms 4 hydrogen bonds with K- Ras (Figure 4.1-4.3). Alpha tocopherol is the second lead molecule with -94.2967 moldock score and -49.117 as the rerank score. It forms 2 hydrogen bonds with Gly101 and His102 of K-Ras. Urs-12-en- 28-ol forms 2 hydrogen bonds with $\operatorname{Arg} 103$ and Val104 and has a moldock score of -84.469 and rerank score of -65.2805. Pentacosenoic acid, 2[(trimethylsilyl)oxy]-methyl ester had a moldock score of -82.7515 and rerank score of -59.8336 . It forms 1 hydrogen bond with Glu167.

The remaining ligands cholest-8-en-3-beta-ol-acetate, 1- octadecyne and Spirost-8-en-11-one,3-hydroxy-(3Beta-5-Alpha-14-beta-20-beta-22-beta-25r) showed moldock scores of $-87.1357,-75.2325$ and -1906.89 respectively. These ligands did not form any hydrogen bond with the target protein K-Ras.

Table 2: List of amino acid residues involved in protein-protein interaction between Human K-Ras (PDB ID: 5O2S) and selected ligands as predicted by SHARP

\begin{tabular}{|c|c|c|c|c|c|}
\hline Name & $\begin{array}{l}\text { MolDock } \\
\text { Score }\end{array}$ & $\begin{array}{c}\text { Rerank } \\
\text { Score }\end{array}$ & $\begin{array}{l}\text { H bond } \\
\text { Energy }\end{array}$ & $\begin{array}{l}\text { No. of } \\
\text { Bonds }\end{array}$ & $\begin{array}{l}\mathrm{H} \text { bond forming } \\
\text { Amino Acids }\end{array}$ \\
\hline DL-.Alpha.-tocopherol & -94.2967 & -49.117 & -2.45354 & 2 & Gly101, His102 \\
\hline 1-octadecyne & -75.2325 & -57.1488 & 0 & 0 & N.A. \\
\hline Phytol & -84.0999 & -66.623 & 0 & 0 & N.A. \\
\hline Ethyl iso-allocholate & -113.594 & -93.3045 & -1.65076 & 4 & $\begin{array}{c}\text { Glu104, Leu103 } \\
\text { Glu63, Tyr64 }\end{array}$ \\
\hline Urs-12-en-28-ol & -84.469 & -65.2805 & -2.97733 & 2 & Arg103, Val104 \\
\hline $\begin{array}{c}\text { Pentacosenoic acid, } \\
2-[(\text { trimethylsilyl)oxy]-, methyl } \\
\text { ester }\end{array}$ & -82.7515 & -59.8336 & 0 & 1 & Glu167 \\
\hline $\begin{array}{l}\text { Spirost-8-en-11-one,3-hydroxy-, } \\
\text { (3.beta.,5.Alpha.,14.beta.,20.beta., } \\
\text { 22.beta.,25r)- }\end{array}$ & 1906.89 & -49.0347 & 0 & 0 & N.A. \\
\hline 8-en-3.beta.-ol, a & -87.1357 & -57.65 & 0 & 0 & N.A. \\
\hline
\end{tabular}

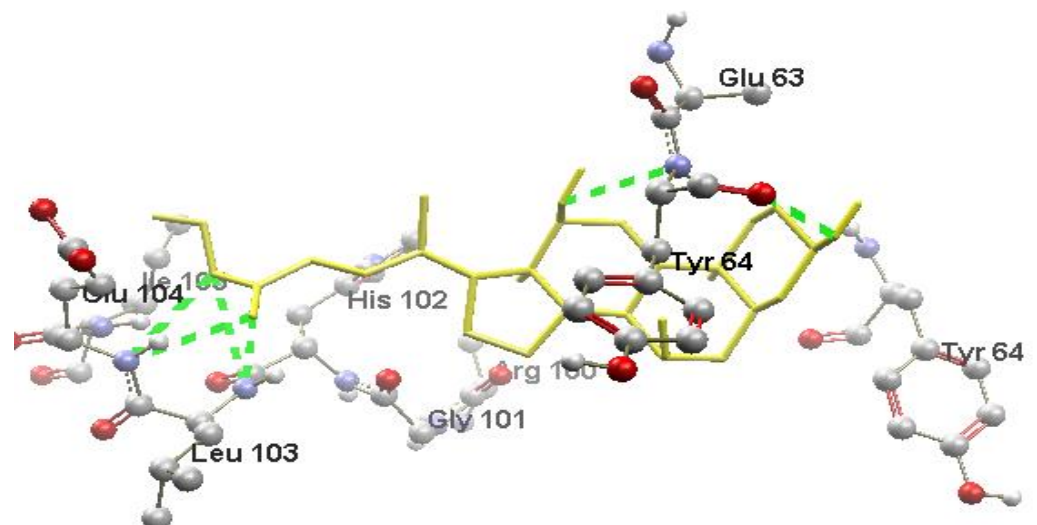

Fig. 4.1: Interaction Profileof Ethyl iso-allocholate with Human K-Ras (PDB ID: 502S). Docking view of Ethyl isoallocholate (Shown in Yellow Stick model) within the active site of Human K-Ras 


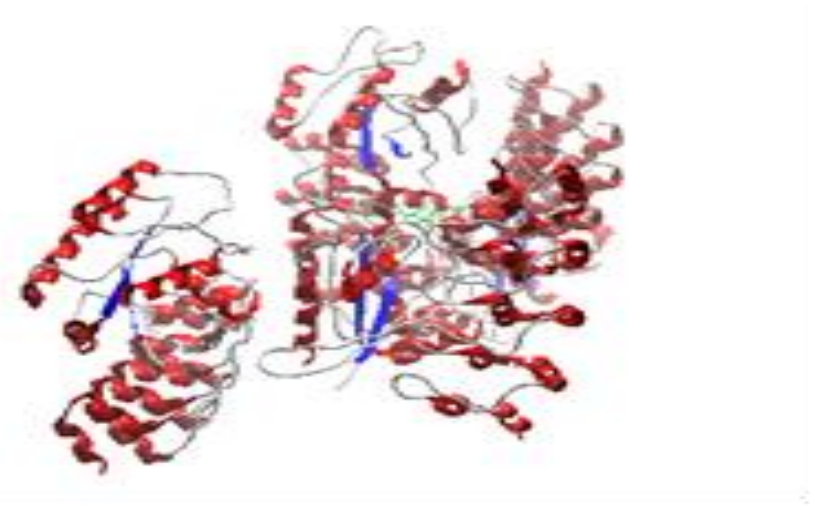

Fig. 4.2: Secondary Structure View of K-Ras in complex with Docked Ethyl iso-allocholate (Shown in Green Stick Model)

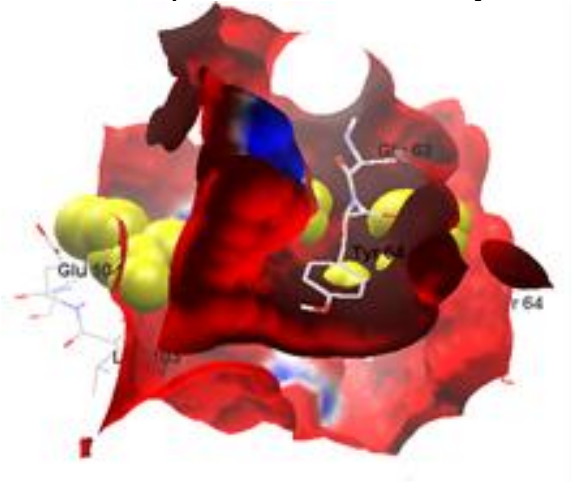

Fig. 4.3: Electrostatic Interactions between Ethyl iso-allocholate (Shown in Yellow Space fill) and Human K-Ras

\section{Docking with Caspase 3}

The docking score and the rerank score of all the eight ligands for caspase 3 was shown in Table 3. It was found that phytol docks better than the other ligands based on the moldock and rerank score. It had a moldock score of -104.653 and -75.718 as the rerank score. It has formed 3 hydrogen bonds with Trp215, Arg207 and Ser206 (Figure 5.1 - 5.3). The second-best molecule was ethyl iso- allocholate with scores of -98.344 and -71.461 as the moldock and rerank score respectively. 4 Hydrogen bonds were formed at Arg207, His121 and Lys163. Cholest-8-en3-beta-ol-acetate showed a moldock score of 96.5463 and rerank score of -73.717 . It formed 2 hydrogen bonds with Ser261 of caspase 3. Though pentacosenoic acid and 1-octadecyne exhibited the next best moldock scores of -93.9333 and -85.0334 respectively, they did not form any hydrogen bonds with caspase 9. Urs-12-en-28-ol has a moldock score of -80.7648 and forms 3 hydrogen bonds with His124, Ser 206 and Arg 64. DL- Alpha tocopherol forms 1 hydrogen bond with Phe 262 and has a moldock score of -76.9024 and a rerank score of 40.771. The least docked ligand with caspase 3 was Spirost-8-en-11-one, 3-hydroxy-(3-Beta-5-Alpha-14beta-20-beta-22-beta-25r). It exhibited a moldock score of -43.65 and rerank score of -45.4561 and with no hydrogen bonds between the ligand and the target protein, Caspase 3.

Table 3: List of amino acid residues involved in protein-protein interaction between Caspase 3 (PDB ID: 1GFW) $\&$ selected ligands as predicted by SHARP

\begin{tabular}{|c|c|c|c|c|c|}
\hline Name & $\begin{array}{l}\text { Mol Dock } \\
\text { Score }\end{array}$ & $\begin{array}{c}\text { Rerank } \\
\text { Score }\end{array}$ & $\begin{array}{l}\text { H bond } \\
\text { Energy }\end{array}$ & $\begin{array}{c}\text { No. of } \mathrm{H} \\
\text { bonds }\end{array}$ & $\begin{array}{c}\mathrm{H} \text { bond forming Amino } \\
\text { Acids }\end{array}$ \\
\hline DL-. Alpha. -tocopherol & -70.9024 & -40.771 & -1.81 & 1 & Phe262 \\
\hline 1-octadecyne & -85.0334 & -67.381 & 0 & 0 & N.A. \\
\hline Phytol & -104.653 & -75.718 & 2.393 & 3 & Trp215, Arg207, Ser206 \\
\hline Ethyl iso-allocholate & -98.344 & -71.461 & -7.72 & 4 & $\begin{array}{c}\text { Arg207, His } 121 \\
\text { Cys } 163\end{array}$ \\
\hline Urs-12-en-28-ol & -80.7648 & -6.57732 & -4.47 & 3 & His124, Ser206.Arg64 \\
\hline $\begin{array}{c}\text { Pentacosenoic acid, 2- } \\
\text { [(trimethylsilyl)oxy]-, methyl ester }\end{array}$ & -93.9333 & -35.1674 & 0 & 0 & N.A. \\
\hline $\begin{array}{c}\text { Spirost-8-en-11-one,3-hydroxy- } \\
\text {,(3.beta.,5.Alpha.,14.beta.,20.beta.,2 } \\
\text { 2.beta.,25r)- }\end{array}$ & -43.65 & -45.4561 & 0 & 0 & N.A. \\
\hline Cholest-8-en-3. beta.-ol, acetate & -96.5453 & -73.717 & -7.35 & 2 & Ser261 \\
\hline
\end{tabular}




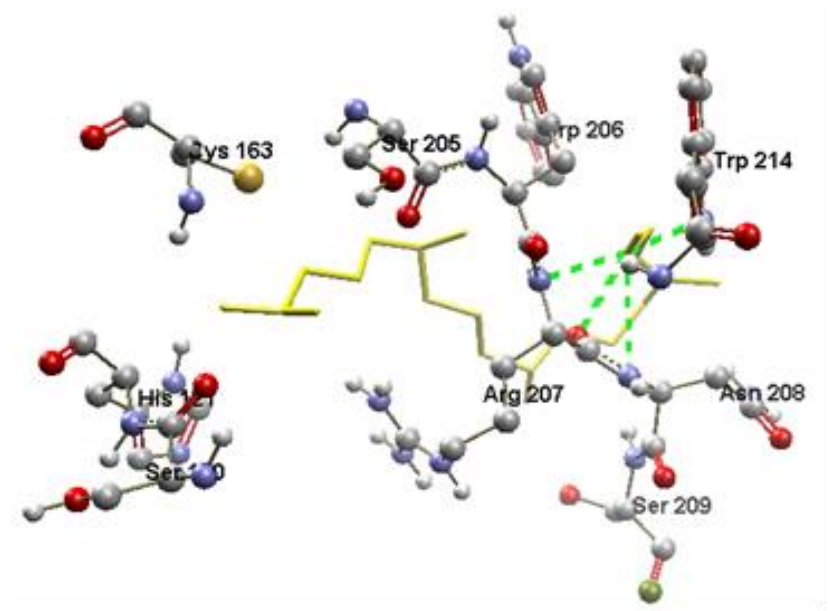

Fig. 5.1: Interaction Profile of Phytol with Human Caspase 3 (PDB ID: 1GFW). Docking view of Phytol Shown in Yellow Stick Model) within the active site of Caspase 3

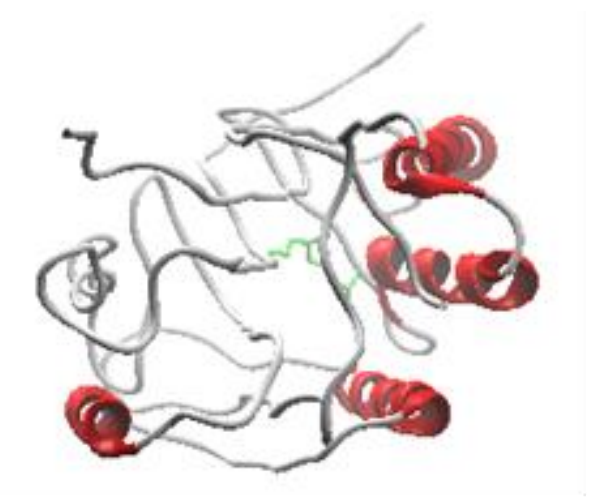

Fig. 5.2: Secondary Structure View of Caspase 3 in complex with Docked Phytol (Shown in Green Stick Model)

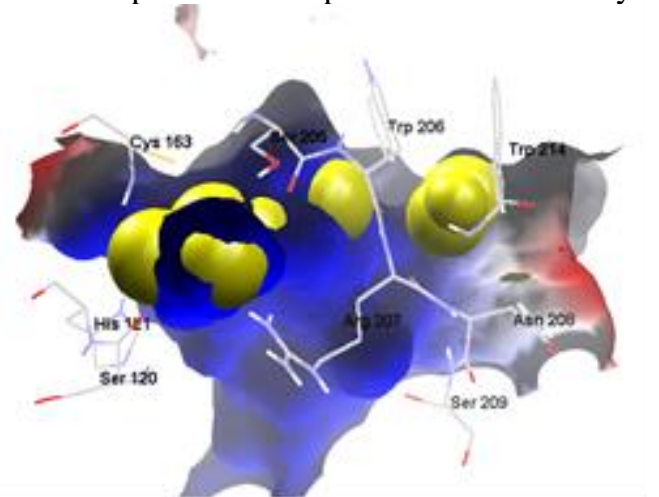

Fig. 5.3: Electrostatic Interactions between Phytol (Shown in Yellow Space fill) and Human Caspase 3

\section{Docking with Caspase 9}

The docking score and rerank score of all the 8 ligands for Caspase 9 was depicted in Table 4. With caspase 9, DL - Alpha tocopherol docks better than other ligands with a least moldock score of about 131.873. Its rerank score was about -101.947 and it forms 2 hydrogen bonds with Asp 228 and Ile 164 (Figure 6.1 - 6.3). Followed by Alpha tocopherol, Cholest-8-en-3, beta-ol-acetate docks with a second least moldock score and rerank score of -124.166 and -75.3847 respectively. But it does not form hydrogen bonds with the target protein whereas Ethyl isoallocholate with a moldock score of -120.944 and rerank score of -95.5794 respectively forms 3 hydrogen bonds with Asp 150 and Ala 149.
Ethyl isoallocholate was followed by Urs-12-en-28ol with a moldock score of about -118.435 and 60.2443 and it had formed 3 hydrogen bonds with 3 amino acids namely Ala 216, Ile 245 and Asp 150. Phytol docks with caspase 9 and forms hydrogen bond with Ala 222. It has a moldock score of about 111.581 and rerank score of about -93.5305 .

The other ligands like pentacosenoic acid, 2(trimethylsilyloxy)-methyl ester; 1- octadecyne does not form any hydrogen bond with caspase 9 and has greater moldock score and rerank score when compared with the lead ligands. The ligand spirost-8en-11-one, 3-OH-(3 Beta,5 Alpha,14 Beta,20 Beta,22 Beta,25r) has very greater moldock score and rerank score of about 4324 and 3434 respectively and hence it docks much lesser with the target protein, Caspase 9. 
Table 4: List of amino acid residues involved in protein-protein interaction between Caspase 9 (PDB ID: 2AR9) \& selected ligands as predicted by SHARP

\begin{tabular}{|c|c|c|c|c|c|}
\hline Name & $\begin{array}{c}\text { MolDock } \\
\text { Score }\end{array}$ & $\begin{array}{c}\text { Rerank } \\
\text { Score }\end{array}$ & $\begin{array}{c}\text { Hbond } \\
\text { Energy }\end{array}$ & $\begin{array}{c}\text { No. of } \\
\text { Hbonds }\end{array}$ & $\begin{array}{c}\text { Hbond forming } \\
\text { Amino Acids }\end{array}$ \\
\hline DL-.Alpha.-tocopherol & -131.873 & -101.947 & -3.53963 & 2 & Asp228, Ile164 \\
\hline 1-octadecyne & -104.727 & -81.1896 & 0 & 0 & N.A \\
\hline Phytol & -111.581 & -93.5305 & -1.81993 & 1 & Ala222 \\
\hline Ethyl iso-allocholate & -120.944 & -95.5794 & -2.92024 & 3 & Asp150, Ala149 \\
\hline Urs-12-en-28-ol & -118.435 & -60.2443 & -2.5 & 3 & $\begin{array}{c}\text { Ala216, Ile245, } \\
\text { Asp150 }\end{array}$ \\
\hline $\begin{array}{c}\text { Pentacosenoic acid, 2- } \\
\text { [(trimethylsilyl)oxy]-, } \\
\text { methyl ester }\end{array}$ & -107.634 & -54.2896 & 0 & 0 & N.A \\
\hline $\begin{array}{c}\text { Spirost-8-en-11-one,3- } \\
\text { hydroxy-, } \\
\left(\begin{array}{c}\text { 3.beta.,5.Alpha.,14.beta.,20. } \\
\text { beta.,22.beta.,25r)- }\end{array}\right.\end{array}$ & 4324 & 3434 & 0 & N.A & N.A \\
\hline $\begin{array}{c}\text { Cholest-8-en-3.beta-ol, } \\
\text { acetate }\end{array}$ & -124.166 & -75.3847 & 0.021 & N.A & N.A \\
\hline
\end{tabular}

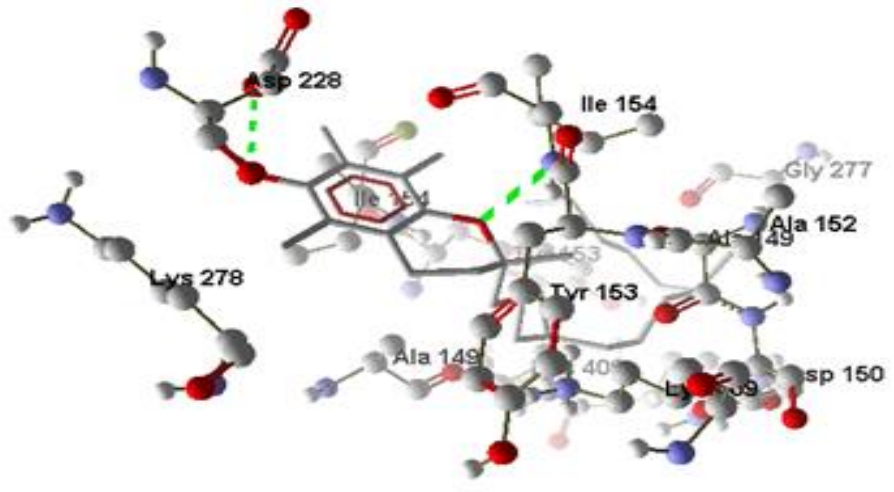

Fig. 6.1: Interaction Profile of DL-.Alpha.-tocopherol with Human Caspase 9 (PDB ID: 2AR9).Docking view of DL-.Alpha.tocopherol within the active site of Human Caspase 9

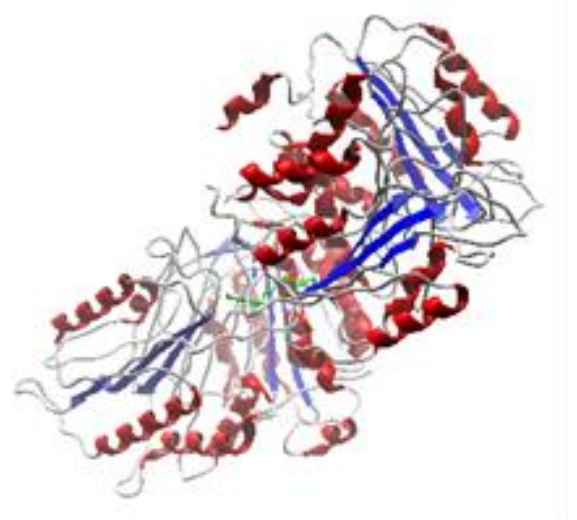

Fig. 6.2: Secondary Structure View of Caspase 9 in complex with Docked DL-.Alpha.-tocopherol (Shown in Green Stick

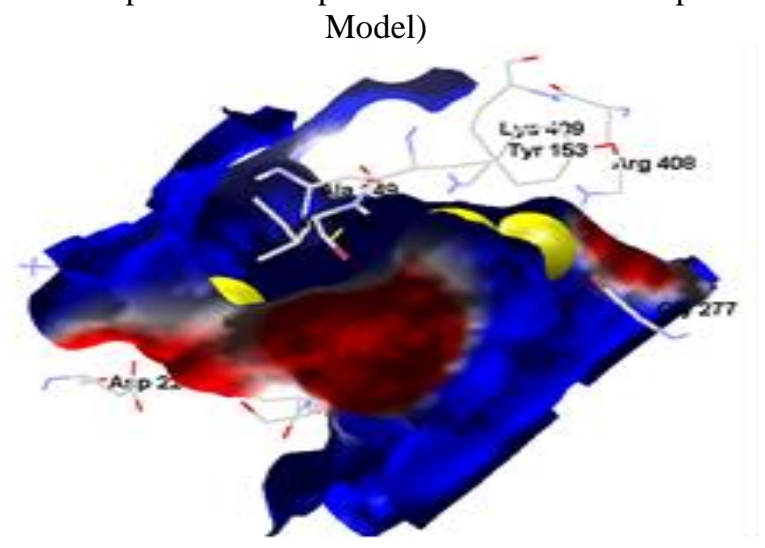

Fig. 6.3: Electrostatic Interactions between DL-.Alpha.-tocopherol and Human Caspase 9 


\section{Docking with Bcl 2}

The docking results for the selected ligands with $\mathrm{Bcl}$ 2 was shown in Table 5. The lead compound was found to be DL-Alpha tocopherol to dock with $\mathrm{Bcl} 2$ with a least moldock score of -107.042. Inspite of having the least score it did not form hydrogen bonds with $\mathrm{Bcl} 2$. The best docked compound with $\mathrm{Bcl} 2$ was ethyl iso-allocholate. It has a least moldock and rerank score of -102.904 and -80.757 respectively. It forms 4 hydrogen bonds with Lys17, Met16, Glu13 and Arg12 (Figure 7.1 - 7.3). The next hydrogen bond forming ligand was cholest-8-en-3-beta-OH

Table 5: Overall Docking Results of the Ligand Interaction with Human BCL2 (PDB ID: 1G5M)

\begin{tabular}{|c|c|c|c|c|c|}
\hline Ligand & $\begin{array}{c}\text { Mol Dock } \\
\text { Score }\end{array}$ & $\begin{array}{c}\text { Rerank } \\
\text { Score }\end{array}$ & $\begin{array}{c}\text { H bond } \\
\text { Energy }\end{array}$ & $\begin{array}{c}\text { No. of H } \\
\text { bonds }\end{array}$ & $\begin{array}{c}\text { H bond forming } \\
\text { Amino Acids }\end{array}$ \\
\hline DL-.Alpha.-tocopherol & -107.042 & -77.8446 & 0 & 0 & N.A \\
\hline 1-octadecyne & -85.7513 & -64.1762 & 0 & 0 & N.A \\
\hline Alpha Amyrin & -98.5525 & -67.5755 & 0 & 0 & N.A \\
\hline Phytol & -93.276 & -66.1394 & -.086874 & 0 & N.A \\
\hline Ethyl iso-allocholate & -102.904 & -80.571 & -4.27957 & 4 & $\begin{array}{c}\text { Lys17,Met16,Glu } \\
\text { 13, } \\
\text { Arg12 }\end{array}$ \\
\hline Urs-12-en-28-ol & -101.973 & -64.0192 & 0 & 0 & N.A \\
\hline Cholest-8-en-3.beta.-ol, acetate & -98.4304 & -62.5763 & -0.68531 & 2 & His20,Tyr21 \\
\hline $\begin{array}{c}\text { Pentacosenoic acid, 2- } \\
\text { [(trimethylsilyl)oxy]-, methyl ester }\end{array}$ & 2132 & 1356 & 7.65 & 0 & N.A \\
\hline $\begin{array}{c}\text { Spirost-8-en-11-one,3-hydroxy-, } \\
\text { (3.beta.,5. }\end{array}$ & 1667 & 1134 & 8.54 & 0 & N.A \\
Alpha.,14.beta.,20.beta.,22.beta.,25r)- & & & & & \\
\hline
\end{tabular}

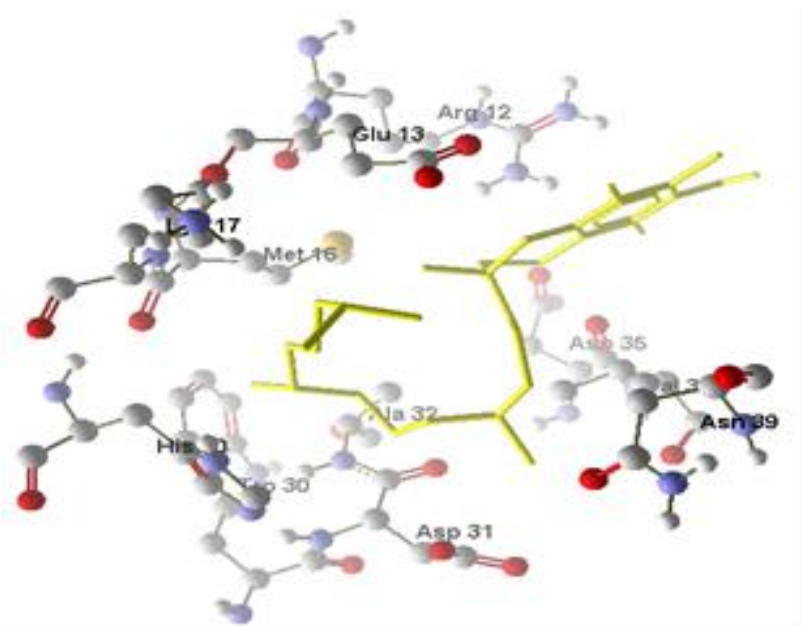

Fig. 7.1: Interaction Profile of DL-.Alpha.-tocopherol with Human BCL2 (PDB ID: 1G5M). Docking view of DL-.Alpha.tocopherol within the active site of Human $\mathrm{Bcl} 2$

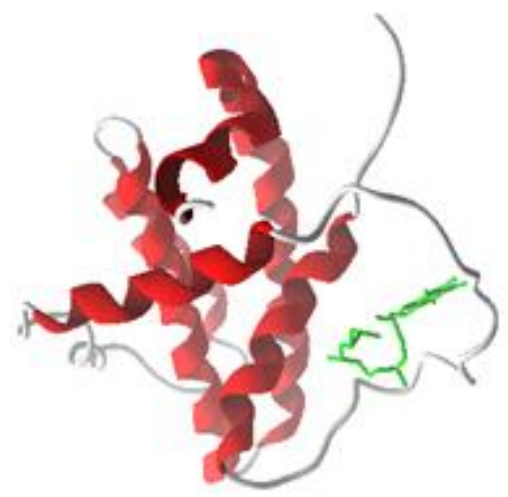

Fig. 7.2: Secondary Structure View of Bcl2 in complex with Docked DL-.Alpha.-tocopherol (Shown in Green Stick Model) 


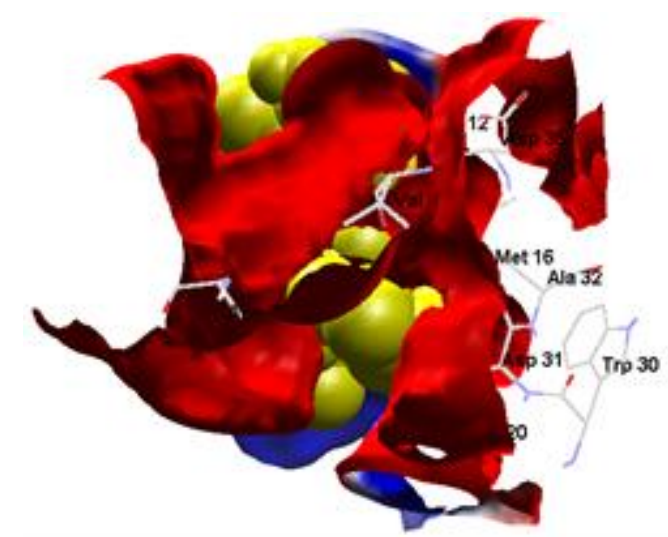

Fig. 7.3: Electrostatic Interactions between DL-.Alpha.-tocopherol and Human Bcl2

\section{Docking with BAX}

The docking score and rerank score for all the eight ligands with BAX was summarized in Table 6. The lead compound to dock with BAX was DL-Alpha tocopherol. It has moldock score of about -136.112 and rerank score of -89.6946. It formed 3 hydrogen bonds with Gly10, Met1and Ser 4 of BAX (Figure $8.1-8.3)$. The next lead compound to dock with BAX is Ethyl isoallocholate. Its moldock score is about -131.981. It forms 6 hydrogen bonds with Ser4, Pro8 and Met1. The compound 1-octadecyne forms 2 hydrogen bonds with BAX at Glu6 and Met1. It is evident from the docking results of all the protein targets that 1- octadecyne could form hydrogen bonds only with BAX and not with other 5 proteins targets namely EGFR, K-Ras, Caspase 3, Caspase 9 and Bcl 2. With BAX, 1- octadecyne has a docking score of -122.129 and rerank score of -97.3539 . It has formed 2 hydrogen bonds with BAX.

The remaining two ligands namely spirost-8-en-11one, 3-OH-(3beta,5 Alpha,14 beta,20 beta,22 beta,25r) and pentacosenoic acid has positive moldock score and rerank score and hence they docked less with the protein target BAX.

Cholest-8-en-3-Beta-ol, acetate, Urs-12-en-28-ol and phytol also has appreciable docking score of $121.809,-112.703$ and -105.542 respectively. But these compounds do not form any hydrogen bond with the BAX protein.

Table 6: Overall Docking Results of the Ligand Interaction with Human BAX (PDB ID: 5O2S)

\begin{tabular}{|c|c|c|c|c|c|}
\hline Ligand & $\begin{array}{c}\text { Mol Dock } \\
\text { Score }\end{array}$ & $\begin{array}{c}\text { Rerank } \\
\text { Score }\end{array}$ & $\begin{array}{c}\text { H bond } \\
\text { Energy }\end{array}$ & $\begin{array}{c}\text { No. of H } \\
\text { bonds }\end{array}$ & $\begin{array}{c}\text { H bond Forming } \\
\text { Amino acids }\end{array}$ \\
\hline DL-Alpha-tocopherol & -136.112 & -89.6946 & -6.0441 & 3 & Gly10, Met1, Ser4 \\
\hline 1-octadecyne & -122.129 & -97.3539 & -2.3245 & 2 & Glu6, Met1 \\
\hline Phytol & -105.542 & -71.9157 & 0 & 0 & N.A. \\
\hline Ethyl iso-allocholate & -131.981 & -35.7543 & -9.99696 & 6 & Ser4, Pro8, Met1 \\
\hline Urs-12-en-28-ol & -112.703 & 115.194 & -3.91786 & 2 & GLU6, ASP2 \\
\hline $\begin{array}{c}\text { Cholest-8-en-3.beta.-ol, acetate } \\
\text { (3.beta.,5.Alpha.,14.beta.,20.beta.,22.beta.,25r)- }\end{array}$ & -121.809 & -92.6714 & 0 & 0 & N.A. \\
\hline $\begin{array}{c}\text { Pentacosenoic acid, 2-[(trimethylsilyl)oxy]-, } \\
\text { methyl ester }\end{array}$ & 72.5467 & 12.8768 & 1.4334 & N.A. & N.A. \\
\hline \begin{tabular}{c} 
Pent-exn-11-one,-454.8723 \\
\hline
\end{tabular} & 4321.6543 & 4,8765 & N.A. & N.A. \\
\hline
\end{tabular}

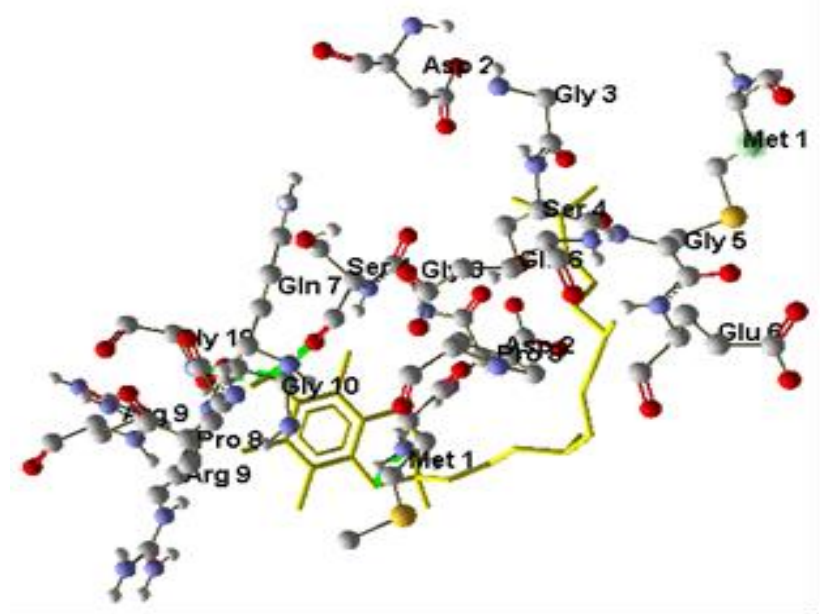

Fig. 8.1: Interaction Profile of DL-Alpha-tocopherol with Human BAX (PDB ID: 1F16). Docking view of DL-Alphatocopherol within the active site of Human BAX 


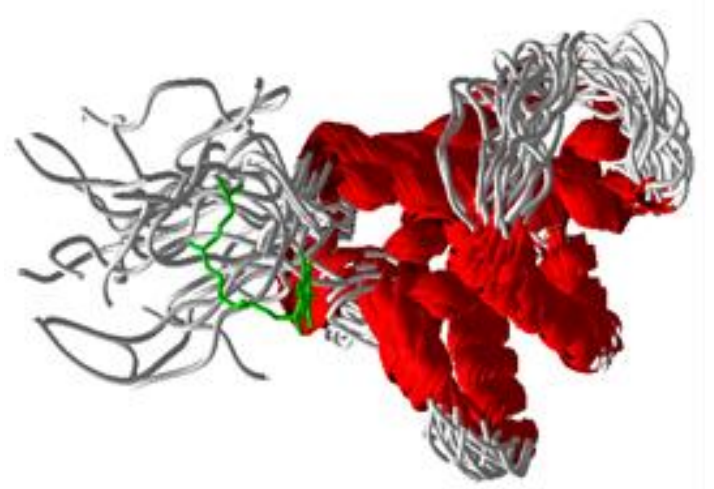

Fig. 8.2: Secondary Structure View of BAX in complex with Docked DL-.Alpha.-tocopherol (Shown in Green Stick Model)

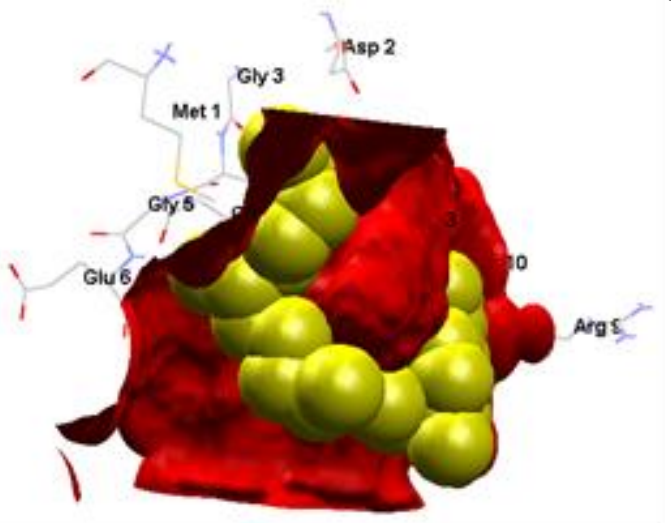

Fig. 8.3: Electrostatic Interactions between DL-. Alpha. -tocopherol and Human BAX

\section{Predicted ADME (Absorption, Distribution, Metabolism and Excretion) properties}

Physically significant descriptors and pharmaceutically relevant properties of all the lead compounds of the ethanolic extract were analyzed using molsoft prediction tool. Molecular weight, log $\mathrm{P}$ Octanol/water partition coefficient, H-bond donors, H-bond acceptors, Mol Log S and their positions according to Lipinski's rule of five were presented in Table 7. Almost all the compounds were in the acceptable range of Lipinski's rule of five, indicating their potential for use as drug-like molecules (6).

Table 7: ADME Prediction - Principal Descriptors of EBT ligands calculated by Lipinski's rule of five using molinspiration

\begin{tabular}{|c|c|c|c|c|c|c|c|c|c|c|}
\hline $\begin{array}{c}\text { Name of } \\
\text { Compound }\end{array}$ & $\begin{array}{c}\text { Molecular } \\
\text { formula }\end{array}$ & M. Wt & $\begin{array}{c}\text { No. of } \\
\text { HBA }\end{array}$ & $\begin{array}{c}\text { No. of } \\
\text { HBD }\end{array}$ & $\begin{array}{c}\text { Mol } \\
\text { logP }\end{array}$ & $\begin{array}{c}\text { Mol } \\
\text { logS }\end{array}$ & $\begin{array}{c}\text { Mol PSA } \\
\text { (in A })\end{array}$ & $\begin{array}{c}\text { Mol Vol } \\
\text { (in A })^{3}\end{array}$ & $\begin{array}{c}\text { No. of } \\
\text { Stereo } \\
\text { Centers }\end{array}$ & $\begin{array}{c}\text { Drug } \\
\text { Likeness } \\
\text { Score }\end{array}$ \\
\hline Phytol & $\mathrm{C}_{20} \mathrm{H}_{40} \mathrm{O}$ & 296.31 & 1 & 1 & 8.28 & -5.27 & 17.17 & 372.58 & 2 & -0.87 \\
\hline $\begin{array}{c}\text { Pentacosenoic } \\
\text { acid, 2- } \\
\text { [trimethylsil } \\
\text { yl)oxy]-, } \\
\text { methyl ester }\end{array}$ & $\mathrm{C}_{29} \mathrm{H}_{58} \mathrm{O}_{3} \mathrm{Si}$ & 484.43 & 3 & 0 & 11.3 & - & 30.24 & 569.46 & 1 & -1.42 \\
\hline $\begin{array}{c}\text { 1.Alpha.,2.Al } \\
\text { pha.-epoxy- } \\
\text { 1.beta.- } \\
\text { methylcholest } \\
\text { a-4,6-dien-3- } \\
\text { one }\end{array}$ & $\mathrm{C}_{28} \mathrm{H}_{42} \mathrm{O}_{2}$ & 384.34 & 1 & 1 & 7.88 & -6.97 & 16.28 & 491.40 & 8 & 0.40 \\
\hline $\begin{array}{c}\text { Ethyl iso- } \\
\text { allocholate }\end{array}$ & $\mathrm{C}_{26} \mathrm{H}_{44} \mathrm{O}_{5}$ & 436.38 & 5 & 3 & 4.67 & -5.06 & 67.67 & 488.84 & 11 & 0.45 \\
\hline $\begin{array}{c}\text { DL-.Alpha.- } \\
\text { tocopherol }\end{array}$ & $\mathrm{C}_{29} \mathrm{H}_{50} \mathrm{O}_{2}$ & 430.38 & 2 & 1 & 10.8 & -8.43 & 21.93 & 522.20 & 3 & 0.49 \\
\hline $\begin{array}{c}\text { Spirost-8-en- } \\
\text { 11-one,3- } \\
\text { hydroxy-, } \\
\text { 3.beta.,5.Alp } \\
\text { ha.,14.beta.,2 } \\
\text { 0.beta.,22.bet }\end{array}$ & $\mathrm{C}_{27} \mathrm{H}_{40} \mathrm{O}_{4}$ & 428.29 & 4 & 1 & 5.04 & -5.79 & 45.14 & 505.01 & 10 & 0.35 \\
\hline
\end{tabular}




\begin{tabular}{|c|c|c|c|c|c|c|c|c|c|c|}
\hline \begin{tabular}{c} 
a.,25r)- \\
\hline $\begin{array}{c}\text { Urs-12-en-28- } \\
\text { ol }\end{array}$
\end{tabular} & $\mathrm{C}_{30} \mathrm{H}_{50} \mathrm{O}$ & 426.39 & 1 & 1 & 9.21 & -8.11 & 15.73 & 566.01 & 10 & 0.09 \\
\hline 1-octadecyne & $\mathrm{C}_{18} \mathrm{H}_{34}$ & 250.27 & 0 & 0 & 7.69 & -7.34 & 0.00 & 330.13 & 0 & -1.18 \\
\hline $\begin{array}{c}\text { Cholest-8-en- } \\
\begin{array}{c}\text { 3.beta.-ol, } \\
\text { acetate }\end{array}\end{array}$ & $\mathrm{C}_{29} \mathrm{H}_{48} \mathrm{O}_{2}$ & 428.37 & 2 & 0 & 8.81 & -6.97 & 20.82 & 534.11 & 7 & 0.82 \\
\hline
\end{tabular}

\section{DISCUSSION}

Lung cancer is a malignant tumor characterized by uncontrolled cell growth in lung tissues. The major risk factor $(85 \%)$ associated with its pathogenesis is tobacco smoking (7). About $10-15 \%$ is because of genetic factors and air pollution (8). Like other cancers, lung cancer is initiated by either the activation of oncogenes or the inactivation of tumor suppressor genes. Mutations of these genes by various carcinogens induce the development of cancer (9).

The genes like K-Ras and EGFR (Epidermal Growth Factor Receptor) plays an important role in lung carcinogenesis. Mutations in the K-Ras protooncogene causes about $10-30 \%$ of lung adenocarcinomas (10). Mutations in EGFR are common in non-small lung carcinoma and thus it provides the basis for treatment with EGFR inhibitors (11). Damage to Bcl2 gene has been identified as a cause for number of cancers including lung, breast, prostate, and melanoma cancer. It is also a cause of resistance to cancer treatments. Over expression of $\mathrm{Bcl} 2$ may increase the risk of cancer. The apoptotic regulator BAX induces apoptosis and hence drugs that activate BAX hold promise an anticancer treatment by inducing apoptosis in cancer cells. The caspases play an essential role in apoptosis. Caspases 3 and 9 are executioner and initiator of apoptosis respectively in humans and mouse (12). The deficiency or inactivation of these caspases has been identified as a cause for tumor development (13).

The present in silico molecular docking study was done to identify the lead compounds present in EBT. For the study, the 3D structures of these six proteins like EGFR, K-Ras, Caspase 3, Caspase 9, BAX and $\mathrm{Bcl} 2$ were downloaded from PDB database, and the docking was done by using MVD. When a ligand binds with a protein, it can either activate or inhibit the proteins. In the present study, the docking studies led to the identification of lead molecules which might play an important role in the activation or inhibition of the protein involved.

From the results, it was evident that proteins like EGFR, K-Ras and Bcl 2 were inhibited or inactivated upon binding with the lead ligands of EBT. Pro apoptotic proteins like BAX, Caspase 3 and Caspase 9 might be activated by the binding of lead molecules of EBT. Similar results have been observed by Gayathri Gunalan et al (14) in the docking studies of
B. variegata secondary metabolites for anticancer activity.

\section{CONCLUSION}

The GC-MS analysis revealed the presence of fourteen secondary metabolites in ethanol extract of the leaves of $B$. tomentosa. Thus, the presence of various bioactive compounds justifies the use of the leaf for various ailments by traditional practitioners. The docking studies revealed that the ligands either activate or inhibit the selected target proteins appropriately. However, isolation of individual secondary metabolites and subjecting it to elucidate their biological activity will be more beneficial. Thus, the ethanol extract of $B$. tomentosa has appreciable anti-cancer activity towards A549 cells. Further separation and purification of individual ligands followed by various analyses might pave way for the identification of new anticancer drugs for the treatment of lung cancer.

\section{ACKNOWLEDGEMENTS}

Authors acknowledge the Department of Biochemistry, Bharathiar University, Coimbatore for giving the opportunity to carry out this research work.

\section{CONFLICT OF INTEREST}

Authors declare that there is no conflict of interest

\section{REFERENCES}

1. Agarwal, N., Chandana, M., Chakraborthy, G. S. Natural herbs as anticancer drugs. Int J PharmTech Res. 2012; 4: 1142-1153.

2. Balabhaskar, R., Vijayalakshmi, K. Evaluation of anticancer activity of ethanol extract of Bauhinia tomentosa linn. on A549, human lung carcinoma cell lines. Research J Pharm and Tech, 2019; 12(6): 2748-2752.

3. Balabhaskar, R., Vijayalakshmi, K. Identification of secondary metabolites from the ethanol extract of the leaves of Bauhinia tomentosa by GC_MS analysis. Research J Pharm and Tech. 2021; 14(5): 2735-2741.

4. Thomsen, R., Christensen, M. H. MolDock: a new technique for high-accuracy molecular docking. J Med Chem. 2006; 49(11): 3315-3321.

5. Wolf, D., Harris, N., Rotter, V. Reconstitution of p53 expression in a non-producer Ab-MuLV-transformed cell line by transfection of a functional p53 gene. Cell. 1984; 38 (1): 119-126.

6. Goodsell, D. S. The Molecular Perspective: Caspases. The Oncologist. 2000: 5 (5): 435-436.

7. Alberg, A. J., Brock, M. V., Samet, J. M. "Chapter 52: Epidemiology of lung cancer". Murray \& Nadel's Textbook of Respiratory Medicine (6th ed.). Saunders Elsevier. 2016.

8. Thun, M. J., Hannan, L. M., Adams - Campbell, L. L., Boffetta, P., Buring, J. E., Feskanich, D., et al., Lung cancer occurrence in never-smokers: an analysis of 13 
cohorts and 22 cancer registry studies. PLoS Medicine. 2008; 5(9): 1357-1371.

9. Cooper, W. A., Lam, D.C., O'Toole, S. A., Minna, J.D. Molecular biology of lung cancer. Journal of Thoracic Disease, 2013; 5(5): S479-S490.

10. Kumar, V., Abbas, A. K., Aster, J. C. "Chapter 5". Robbins Basic Pathology (9th ed.). Elsevier Saunders. 2013: p. 212.

11. Herbst, R. S., Heymach, J. V., Lippman, S. M. Lung cancer. N Engl J Med. 2008; 359(13): 1367-1380.

12. Lorenzo, G., López-Soto, A., Kumar, S., Kroemer, G. Caspases Connect Cell-Death Signaling to Organismal Homeostasis. Immunity, 2016; 44(2): 221-231.

13. Lipinski, C. A., Lombardo, F., Dominy, B. W., Feeney, P. J. Experimental and computational approaches to estimate solubility and permeability in drug discovery and development settings. Adv Drug Deliv Rev. 2001; 46(1-3): 3-26.

14. Gunalan, G., Vijayalakshmi, K., Tamilvannan, T., Hopper. W. Anticancer activity of secondary metabolites from Bauhinia variegata Linn.Leaf - an in silico approach. Indo American Journal of Pharmaceutical Research. 2016; 6(7): 6299-6311. 